Nat. Hazards Earth Syst. Sci. Discuss., doi:10.5194/nhess-2017-61, 2017

Manuscript under review for journal Nat. Hazards Earth Syst. Sci.

Discussion started: 20 February 2017

(C) Author(s) 2017. CC-BY 3.0 License.

\title{
Design Considerations of Artificial Mangrove Embankments for Mitigating Coastal Floods - Adapting to Sea-level Rise and Long-term Subsidence
}

Hiroshi Takagi ${ }^{1}$

${ }^{1}$ School of Environment and Society, Tokyo Institute of Technology, Tokyo, Japan

5 Correspondence to: H. Takagi (takagi@ide.titech.ac.jp)

\begin{abstract}
.
Mangrove plantation belts are expected to act as natural infrastructural buffers against coastal hazards. However, their performance will not endure over time if the platform is not appropriately designed. In fact, despite massive funds dedicated to the rehabilitation of mangrove forests, the long-term survival rates of mangroves are generally low. This paper investigates the function of mangrove embankments in attenuating the amplitudes of ocean tides through a coupled numerical model that reproduces shallow-water wave propagations under the progress of soil consolidation. The developed model is capable of simulating tidal propagation over an artificial embankment, which will inevitably change its ground surface elevation with the passage of time because of sea-level rise, land subsidence, vegetation growth and sediment accretion. A parametric analysis demonstrates that high tides could be effectively mitigated only if the embankment is appropriately designed to maintain an equilibrium state among these multiple influences over the long term. On the other hand, an embankment designed without considering geomorphological transitions will become submerged under the rising sea level, resulting in no significant effect on tidal damping. Therefore, the artificial mangrove embankment must be carefully designed to function not only during the initial stage of its lifetime but also over time, to avoid system failure in the future.
\end{abstract}

Keywords: Ecological disaster risk reduction (Eco-DRR), mangrove, ocean tide, embankment, subsidence, soil consolidation, sea-level rise, sediment accretion, a coupled numerical model 
Nat. Hazards Earth Syst. Sci. Discuss., doi:10.5194/nhess-2017-61, 2017

Manuscript under review for journal Nat. Hazards Earth Syst. Sci.

Discussion started: 20 February 2017

(c) Author(s) 2017. CC-BY 3.0 License.

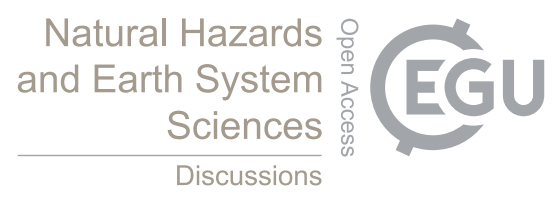

\section{INTRODUCTION}

Mangrove forests are expected to act as natural infrastructural buffers against natural hazards. In fact, a number of field surveys conducted after recent major disasters such as the 2004 Indian Ocean Tsunami and the 2013 Typhoon Haiyan have confirmed the mitigation effect of mangroves against tsunamis, storm surges, and

5 high waves (e.g., Wolanski et al., 2009; Ellison, 2009; Teh et al., 2009; Narayan et al., 2010; Rasmeemasmuang and Sasaki, 2015; Mikami et al., 2016). Such function of vegetation has also been confirmed by laboratory experiments that imposed tsunami-like bores in a wave flume (Irtem et al., 2009; Iimura and Tanaka, 2012; Strusinska-Correia et al., 2013). Takagi et al. (2016a) demonstrated that the impact of a type of tsunami induced by a sudden dyke failure would be substantially mitigated by planting a mangrove belt in front of the dyke,

10 through two mechanisms: (1) a reduction in floodwater velocity and inundation depth and (2) a flow smoothing effect, which reduces strong turbulence. Salt marshes have also been shown to significantly reduce wave loads on coastal dykes (Vuik et al., 2016). Vegetation decreases wave height and run-up height as plant diameter and/or stem density increase (Tang et al., 2017).

By protecting coastal environments against shoreline change, mangroves also increase the shoreline's 15 resilience with regard to recovering from a disturbance (Alongi, 2008). Further advantages associated with mangrove include sediment trapping, flood protection, nutrient recycling, wildlife habitat and nurseries (Primavera and Esteban, 2008). These mangrove advantages are collectively referred to as ecological resilience (Gunderson et al., 2002).

Given these advantages, the function of mangroves in Ecosystem-based Disaster Risk Reduction (hereinafter referred to as Eco-DRR) has drawn attention worldwide. Appropriate management of ecosystems can be harnessed to reduce both disaster risks and climate-related risks (UNEP, 2012; UNEP, 2015; CNRD-PEDRR, 2013). In order to implement Eco-DRR, however, the effectiveness of ecosystems in reducing the impacts of natural hazards needs to be quantitatively and practically evaluated. In fact, despite massive funds dedicated to the rehabilitation of mangrove forests over the last two decades, the long-term survival rates of mangroves are generally low, at $10-20 \%$ in the case of the Philippines (Primavera and Esteban, 2008).

The present study investigates the application of mangrove forests as a countermeasure for disaster mitigation particularly in urban areas, which are currently experiencing land subsidence and sea-level rise (SLR). For example, Jakarta, one of the fastest growing megacities in the world, experienced subsidence rates varying from 9.5 to $21.5 \mathrm{~cm}_{\text {year }}{ }^{-1}$ in the period between 2007 and 2009, exacerbating coastal flooding issues (Chaussard et al., 2013; Takagi et al., 2016b). The Chao Phraya Delta in Thailand has been sinking by $5-15 \mathrm{~cm} \mathrm{year}^{-1}$ and the Mekong Delta by $2 \mathrm{~cm}$ year-1 because of intense groundwater use and/or natural consolidation (Giosan et al., 
Nat. Hazards Earth Syst. Sci. Discuss., doi:10.5194/nhess-2017-61, 2017

Manuscript under review for journal Nat. Hazards Earth Syst. Sci.

Discussion started: 20 February 2017

(c) Author(s) 2017. CC-BY 3.0 License.

(c) (i)

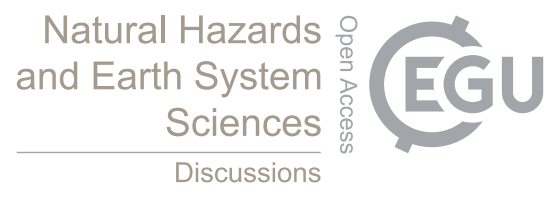

2014; Takagi et al., 2016c). On the other hand, the vertical accretion of sediment in mangrove forests is relatively slow, at the rate of several mm year-1 (Krauss et al., 2014; Lovelock et al., 2015). Therefore, the response of a mangrove forest to external influences such as SLR and ground subsidence determines the forest's capacity to maintain itself at the pace necessary to adapt to the changing sea level. It is likely that planting mangroves

5 without considering such rapid subsidence will result in the forest's submergence under the sea in a short period of the time. When applying an artificial mangrove forest as an Eco-DRR option for coasts experiencing rapid subsidence, an engineering design method that takes into account subsidence as well as SLR will be required to aid planners and engineers in determining the appropriate project specifications.

There are relatively few studies on tides propagating through mangroves, compared to the number of studies on wind waves, storm surges and tsunamis, which have been extensively studied over the last several decades. Therefore, the present study evaluates mangrove embankments against tidal propagations in order to quantify the function of mangroves in attenuating tidal amplitudes, considering long-term influences such as vegetation growth, SLR, subsidence and sediment accretion. Mangrove platform designs are also investigated to determine which designs can adapt at the same pace as the changing sea level, to maximise the mangrove forest's long-term serviceability as a flood mitigation measure.

\section{METHODOLOGY}

This chapter first describes the concept of an artificial mangrove embankment. The numerical model developed to simulate tidal propagation through a sinking mangrove forest is then briefly explained. Finally, the computational conditions for a case study are described.

\subsection{Concept of Artificial Mangrove Embankment}

Coastal areas, particularly in developing countries, are facing increasing disaster risks due to many emerging issues such as rapid population increases, SLR, land subsidence and poor and/or aging infrastructure. Ecosystem platforms are expected to reduce disaster risks as well as climate-related impacts. Figure 1 illustrates (a) a high tide overflowing a coastal dyke and resulting in extensive inundation and (b) an artificial mangrove forest designed to mitigate flood damage, adopted as an Eco-DRR countermeasure. A front part of the embankment is initially formed in a stable trapezoidal shape by adding soil fill with a slope of $1 / 5$ or less (Scenario 1 ). In this initial stage, the embankment functions in the same manner as a dyke structure because the ground surface elevation is higher than the high tides. However, the platform will immediately start sinking because of soil 
Nat. Hazards Earth Syst. Sci. Discuss., doi:10.5194/nhess-2017-61, 2017

Manuscript under review for journal Nat. Hazards Earth Syst. Sci.

Discussion started: 20 February 2017

(c) Author(s) 2017. CC-BY 3.0 License.

consolidation resulting from the soil's weight and/or forced displacement due to land subsidence in adjacent lands. Two additional scenarios that could occur over many years are also illustrated in the figure. Scenario 2 represents the case in which the embankment is maintained with the changing sea level by achieving an equilibrium state between subsidence, SLR and sediment accretion over the mangrove bed. On the other hand,

5 Scenario 3 shows that the embankment designed without considering long-term evolutions will become submerged under mean sea level (MSL). In this state, the mangrove forest cannot expand because high waves pass across the embankment without sufficient attenuation, resulting in less sediment trapping and no significant effect on tidal damping.

\subsection{Shallow Water Wave - Soil Consolidation Integrated Model}

Waves propagating in shallow water (relative water depth: $h / L<1 / 20$ ) are called shallow water waves (or long waves); this wave type includes ocean tides, tsunamis and storm surges. Shallow water waves can be simulated by solving the following governing equations: the equation of motion, Equation (1), and the continuity equation, Equation (2) (e.g., Kowalik and Murty, 1993):

15

$$
\begin{gathered}
\frac{\partial U}{\partial t}+U \frac{\partial U}{\partial x}+g \frac{\partial \eta}{\partial x}+\frac{g n^{2}|U| U}{h^{\frac{4}{3}}}=0 \\
\frac{\partial \eta}{\partial t}+\frac{\partial(h+\eta) U}{\partial x}=0
\end{gathered}
$$

In Equations (1) and (2), $U$ is the depth-averaged velocity, $\eta$ is the water displacement, $h$ is the water depth, $g$ is the gravitational acceleration and $n$ is Manning's $n$ value. In the present model, these governing equations are discretised by the finite difference method with staggered grids. The spatial derivatives are approximated by central differences, whereas the time derivatives are discretised by forward differences.

Consolidation is the process whereby an increase in stress gradually causes a volume reduction as water is released from the soil. This term should not be confused with compaction, which is an instantaneous change in the soil volume due to a mechanical impact. In the shallow water wave - soil consolidation integrated model developed for this study, the water depth used in Equations (1) and (2) is adjusted to the ground subsidence that is calculated by the following Terzaghi one-dimensional consolidation equation (e.g., Wesley, 2010; Knappett and Craig, 2011): 
Nat. Hazards Earth Syst. Sci. Discuss., doi:10.5194/nhess-2017-61, 2017

Manuscript under review for journal Nat. Hazards Earth Syst. Sci.

Discussion started: 20 February 2017

(c) Author(s) 2017. CC-BY 3.0 License.

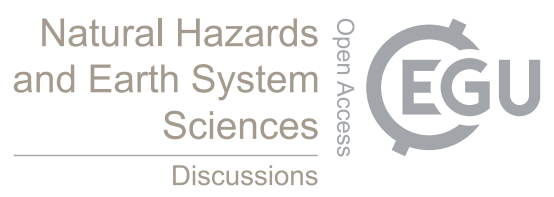

(c) $\underset{\mathrm{BY}}{(i)}$

$$
\frac{\partial u_{e}}{\partial t}=C_{v} \frac{\partial^{2} u_{e}}{\partial z^{2}}
$$

where $C_{v}$ is the coefficient of consolidation, $u_{e}$ is the excess pore pressure during consolidation, $t$ is time and $z$ is the vertical ordinate.

A non-dimensional form of Equation (3) is derived by introducing $Z=z / H_{d}$ and $T=C_{v} t / H_{d}^{2}$ :

$$
\frac{\partial u_{e}}{\partial T}=\frac{\partial^{2} u_{e}}{\partial Z^{2}}
$$

where $H_{d}$ is the drainage path length, which is either half the layer thickness (when drainage can occur at both boundaries) or the full layer thickness (when drainage can only occur at one boundary). Equation (4) is equivalent to the 1-D heat equation and can be solved analytically with initial and boundary conditions. The solution is derived by assuming the initial condition of $u_{e}$ as a load $q_{s}$ created by the embankment as follows:

$$
u_{e}=q_{s} \sum_{n=0}^{\infty} \frac{2(-1)^{n} \cos \left(a_{n} Z\right)}{a_{n}} \exp \left(-a_{n}^{2} T\right)
$$

15

where $a_{n}=(2 n+1) \pi / 2$. The estimated final subsidence is then calculated by Equation (6) with a compression index $C_{c}$ that is assumed to remain constant throughout a compressible soil. The subsidence $S_{c}$ at a given time $T$ can also be calculated by Equations (7) and (8) with the degree of consolidation $U$.

$$
\begin{aligned}
& S_{f}=\frac{C_{c}}{1+e_{0}} H \log _{10}\left(1+\frac{q_{s}}{\sigma^{\prime}}\right) \\
& S_{c}=S_{f} U(T) \\
& U(T)=1-\sum_{n=0}^{\infty} \frac{2}{a_{n}^{2}} \exp \left(-a_{n}^{2} T\right)
\end{aligned}
$$

The effective vertical stress $\sigma^{\prime}$ in Equation (6) can be calculated by referencing the method of vertical stress due to embankment loading (Osterberg, 1957). 
Nat. Hazards Earth Syst. Sci. Discuss., doi:10.5194/nhess-2017-61, 2017

Manuscript under review for journal Nat. Hazards Earth Syst. Sci.

Discussion started: 20 February 2017

(c) Author(s) 2017. CC-BY 3.0 License.

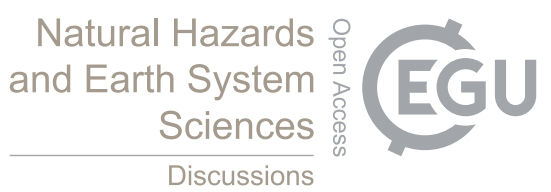

Although the present paper considers only the subsidence $S_{c}$ associated with soil consolidation due to the surplus weight of the embankment, regional land subsidence $S_{r}$ (often caused by groundwater withdrawals) should also be considered in relevant cases, leading to the following resultant subsidence $S_{t}$.

$$
S_{t}=S_{c}+S_{r}
$$

\subsection{Resistance of Mangrove Forest}

The tidal flows become more complex when eddies, jets and stagnation are created by the resistance of the mangrove forest. Vegetation resistance is composed of two factors: energy losses due to friction and drag due to the variable velocities (Furukawa and Wolanski, 1996; Lewis, 1997; Green, 2005). Drag force related to plant length, diameter, Reynolds number and vegetation density have been simulated by previous studies (e.g., Mazda et al., 1997; Strusinska-Correia et al., 2013; Maza et al., 2015; Losada et al., 2016). Because the shallow water wave model represented by Equation (1) accounts for only bottom friction, the effect of drag can be taken into account solely through Manning's $n$ value. Whereas coastal or riverine areas without dense vegetation are often assumed to have a relatively small $n$ value in the range of 0.02-0.03 (Bricker et al., 2015), a much greater value needs to be applied when the flow in an area of dense vegetation is simulated. In addition, coefficient values tested on large-depth flows should not be simply applied to small-depth flows such as a vegetation bed (Diaz, 2005). Table 1 summarises the Manning's $n$ values that were proposed in the previous papers on flood mitigation effects of various type of vegetation. Although the $n$ values vary according to conditions, the present study assumes the $n$ value of $0.3\left(\mathrm{~s} \mathrm{~m}^{-1 / 3}\right)$ in Equation (1) to represent a fully grown mangrove forest; this value was selected as the average of those listed in Table 1. On the other hand, the value for a bare embankment condition (namely, landfill with no mangrove vegetation) was assumed to have a much smaller $n$ value of 0.025 , which is commonly used for the roughness of a seabed (Bricker et al., 2015).

\subsection{Sediment Accretion Rate}

Mangroves are expected to naturally respond to relative sea-level rise and thus may not require maintenance as a flood protection measure. Accretion in these wetlands occurs because of the accumulation of organic matter produced by the plants themselves (Valiela, 2006). Many field investigations on sediment trapping rates suggest that many coastal marshes accrete at rates comparable to SLR (e.g., Lynch et al., 1989; Day and Templet, 1989; Wood et al., 1989; Kearney et al., 1994; Parkinson et al., 1994). For instance, Blum and Christian (2004) present an organic sediment accretion of $9 \mathrm{~mm} \mathrm{yr}^{-1}$ for a marsh covered by Spartina alterniflora in Virginia, in the United 
Nat. Hazards Earth Syst. Sci. Discuss., doi:10.5194/nhess-2017-61, 2017

Manuscript under review for journal Nat. Hazards Earth Syst. Sci.

Discussion started: 20 February 2017

(c) Author(s) 2017. CC-BY 3.0 License.
Natural Hazards

and Earth System

Sciences

Discussions

(c) $\underset{\mathrm{BY}}{(i)}$

States. Saad et al. (1999) conducted an extensive two-year field survey in an estuarine mangrove swamp. They sampled surface sediment in both non-monsoon and monsoon periods at 52 stations and found that the accretion rate was $1.46 \pm 0.13 \mathrm{~cm} \mathrm{yr}^{-1}$ and $0.66 \pm 0.04 \mathrm{~cm} \mathrm{yr}^{-1}$ for the first and second year, respectively, for an average of $1.06 \mathrm{~cm} \mathrm{yr}^{-1}$. Although the annual deposit rate varies to a great extent, based on these previous studies, the present

5 study assumes that sediment accretion will occur at the rate of $1 \mathrm{~cm} \mathrm{yr}^{-1}$ over the embankment's long-term transition induced by the amount of time over which the embankment's surface is lower than MSL.

\subsection{Computational Conditions for the Case Study}

A case analysis was conducted to investigate how mangrove plantations can mitigate tide propagation across the embankment. Numerical settings and other important assumptions applied in the numerical analysis are summarised as follows.

- Time span of the analysis: 100 years after the completion of the landfill.

- Spatial grid: $50 \mathrm{~m} \times 600$ grids $=30 \mathrm{~km}$ in the cross-sectional direction.

- Original bathymetry: Varying from a 10-m depth offshore to a 1.5-m depth onshore; the mangrove embankment is created on top of the original bathymetry.

- Embankment heights (thicknesses): 2, 3, 4 and $5 \mathrm{~m}$.

- Time increment for shallow water wave computation: $0.2 \mathrm{~s}$.

- Boundary condition: A diurnal tide with amplitude of $0.3 \mathrm{~m}$.

- Computational time: 24 hours, which can fully encompass one tidal cycle.

- Sediment accretion on the embankment will start after the mangrove plants are fully grown.

- Mangrove plants will be fully grown in 10 years.

- Bottom roughness, represented by Manning's $n$, will linearly increase from the initial value of 0.025 (the embankment not covered by vegetation) to the final value of 0.30 (fully covered by vegetation) over the growing period.

- Soil consolidation parameters: $C_{c}=1.0 ; C_{v}=85.0 \mathrm{~cm}^{2}$ day $^{-1}$.

- A mangrove embankment filled by sand (unit weight of $21 \mathrm{kN} \mathrm{m}^{-3}$ ) is to be placed on top of the clay seabed layer (unit weight of $18 \mathrm{kN} \mathrm{m}^{-3}$ ); the consolidation process occurs only in the clay layer, of which the thickness is assumed to be $18.5 \mathrm{~m}$ (from $-1.5 \mathrm{~m}$ down to $-20 \mathrm{~m}$ MSL). 
Nat. Hazards Earth Syst. Sci. Discuss., doi:10.5194/nhess-2017-61, 2017

Manuscript under review for journal Nat. Hazards Earth Syst. Sci.

Discussion started: 20 February 2017

(c) Author(s) 2017. CC-BY 3.0 License.

Because there are many parameters that influence the scenarios in the case analysis, several parameters such as soil parameters and tidal condition were determined by reference to the condition in the Jakarta Bay (Takagi et al. 2016b).

\section{RESULTS}

In this section, the performance of the mangrove embankment in mitigating tidal propagation is discussed based on the results of the case analysis.

\subsection{Changes in Ground Elevation over Many Years}

Figure 2 (b) shows the hypothetical geometry of the mangrove embankment created by filling soil on a shallow water bay with a constant water depth of $1.5 \mathrm{~m}$, as illustrated in Figure 2 (a). Here, two initial design selections are considered as examples: a high embankment with a mound thickness of $5 \mathrm{~m}$ (elevation $+3.5 \mathrm{~m})$ and a low embankment with a mound thickness of $2 \mathrm{~m}(+0.5 \mathrm{~m})$. Although both of these embankments are expected to become submerged after 60 years as shown in Figure 2 (c), the ground surface remains close to the sea level when the initial thickness is set to be $5 \mathrm{~m}$. On the other hand, for the case of a $2 \mathrm{~m}$ thickness, the water depth was found to be nearly $1.5 \mathrm{~m}$, which is the same as the pre-fill soil level. Therefore, a high-elevation embankment may be the countermeasure with the best long-term performance, whereas a low-elevation embankment may function effectively in the very beginning, but would lose functionality after many years.

Because mangroves function to trap sediment, mangrove forests could become an important sink for suspended sediment (e.g., Woodroffe, 1992; Furukawa et al., 1997). Given the situation in which both SLR and subsidence inevitably occur, sediment accretion only raises the ground level and keeps the mangrove surface even with the sea level. Therefore, it would not be possible to achieve a sustainable mangrove embankment system in the case that organic or other suspended matter fails to sink to the ground surface, e.g., due to strong turbulence and sediment pick-up caused by high waves.

Figure 3 illustrates how changes in the ground elevation over time could differ with and without sediment accumulation. The difference is particularly clear for the case of the 5-m-high embankment, shown by the blue continuous line. In the first 40 years, sediment accretion is not yet calculated because the ground elevation remains above the water surface; hence, the identical lines for the cases with and without sediment accumulation over this time period. However, at approximately the $50^{\text {th }}$ year, the ground starts to become inundated. The embankment with accretion, which receives sediment deposition at the rate of $1 \mathrm{~cm} \mathrm{yr}^{-1}$, is likely to maintain its surface level with the sea level, demonstrating a successful tide attenuation scenario. In contrast, the lower 
Nat. Hazards Earth Syst. Sci. Discuss., doi:10.5194/nhess-2017-61, 2017

Manuscript under review for journal Nat. Hazards Earth Syst. Sci.

Discussion started: 20 February 2017

(c) Author(s) 2017. CC-BY 3.0 License.

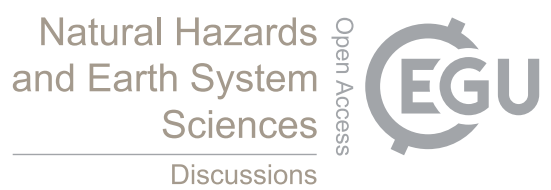

(c) (i)

embankment, such as that with a 2-m-height, may not substantially contribute to a reduced water level. This is because the water depth above the ground is too deep to effectively reduce the tidal energy, irrespective of whether sediment accretion is expected.

5 3.2 Tidal Propagations over the Mangrove Embankments

Suspended sediment trapped by mangroves is highly dependent on the extent to which the plants are fully grown. The water depth above the embankment and the embankment width appear to be predominant influences on tidal attenuation. Among many influential factors, these three parameters in particular must be carefully examined in the designing phase. Figure 4 shows how the effectiveness of the mangrove embankment as a tidal attenuator would vary with changes in those values.

The present model assumes that the vegetation growth ratio starts from $0 \%$, and the vegetation growth ratio is assumed to linearly increase up to $100 \%$ after 10 years. The tidal amplitude is not significantly attenuated when the vegetation growth ratio is low. For example, tidal propagation is not disturbed when the water depth is $1 \mathrm{~m}$ and no vegetation covers the ground. However, if the mangrove embankment can be designed to be as wide as

$15500 \mathrm{~m}$, an amplitude reduction of approximately $40 \%$ is expected when the plants are fully grown. The figures demonstrate that the embankment width can be shortened by $200 \mathrm{~m}$, with a corresponding tidal amplitude reduction $40-50 \%$ if the water depth can be kept lower than $50 \mathrm{~cm}$.

In addition, the backwash during the ebb tide is hindered because of the bed friction increased by the vegetation. The friction increase also induces a delay in the tidal phase of up to a few hours. This retention of seawater should provide a favourably serene water environment for marine organisms, and the currents around the vegetation create stagnation zones where the suspended sediment will settle. On the other hand, water pollution or flood issues may also arise in highly populated coasts because of the inevitable water stagnation. The time series demonstrates that the tide becomes asymmetrical in mangroves because of the resistance offered by mangrove vegetation. The signal modification is clearly apparent starting at the time when the water begins to inundate the swamp, and it is especially pronounced around the time when the bottom substrate becomes dry at ebb tide, as presented by Mazda and Kamiyama (2007).

Figure 5 summarises the tidal attenuation ratios that indicate to what extent an incident tide is attenuated by the mangrove embankment according to the embankment's width and the water's depth. The maximum attenuation at the water depth of $30 \mathrm{~cm}$ and the width of $500 \mathrm{~m}$ is $64 \%$ when the vegetation is fully grown, whereas only $12 \%$ attenuation is expected immediately after the construction of the embankment. Equation (1) indicates that the bottom friction rapidly increases in proportion to the square of the velocity. Therefore, the 
Nat. Hazards Earth Syst. Sci. Discuss., doi:10.5194/nhess-2017-61, 2017

Manuscript under review for journal Nat. Hazards Earth Syst. Sci.

Discussion started: 20 February 2017

(c) Author(s) 2017. CC-BY 3.0 License.

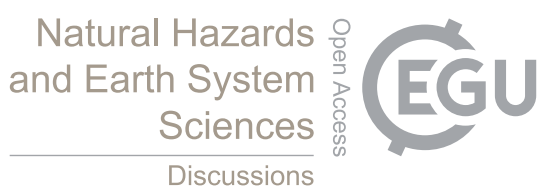

(c) (i)

growth ratio, which indicates how strongly the vegetation resists the tidal flow, appears to be one of the predominant design factors that should be considered.

\section{DISCUSSION}

The results presented in the previous section confirm that the mangrove embankment will not effectively mitigate tidal floods unless it is carefully designed with forethought regarding future morphological transitions. On the other hand, it may be possible to achieve an equilibrium state if the elevation of the mangrove embankment is balanced between multiple factors such as sea-level rise, land subsidence, vegetation growth and sediment accretion. In this case, the system is expected to be sufficiently sustainable that expensive maintenance work will not be required over the mangrove forest's lifetime. The following insights are expected to help planners design effective mangrove embankments.

Initial elevations must be sufficiently high to avoid being totally submerged: Mangroves can cover a wide intertidal area, which is flooded at high tide and exposed at low tide, and mangroves normally grow in areas between the middle tide level and the highest high water spring tide. Within the intertidal zone, species prefer different elevations, salinities and inundation frequencies (Global Nature Fund, 2007; Wolanski et al., 2009). Therefore, the mangrove plantation is expected to be most effective within the intertidal zone. However, this general guideline may not always be successful when the plantation is implemented on sinking ground.

Narrower mangrove embankments will not be effective as tidal attenuators: Unlike wind waves, long tidal waves cannot be easily attenuated. A wider embankment covered by mangroves is thus required for a substantial mitigation effect. However, on most urban coasts with high populations, mangrove plantations may be allowed within only limited spaces. In such a case, the effectiveness of a narrow embankment should not be overestimated as a tidal attenuator.

Mangroves retain seawater, creating both positive and negative influences: Increased resistance due to the high density of mangrove vegetation induces the retention of seawater on the ground during the ebb tide phase. A tranquil water environment is beneficial for marine organisms and animals and thereby fosters biodiversity; on the other hand, stagnant water may exacerbate urban floods because the stagnant water may inhibit the discharge 
Nat. Hazards Earth Syst. Sci. Discuss., doi:10.5194/nhess-2017-61, 2017

Manuscript under review for journal Nat. Hazards Earth Syst. Sci.

Discussion started: 20 February 2017

(c) Author(s) 2017. CC-BY 3.0 License.

(c) (i)

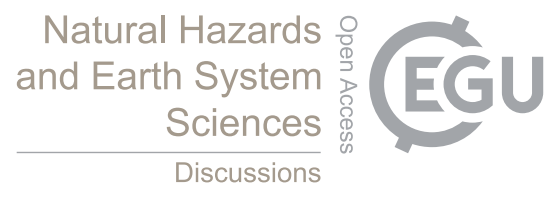

of storm water into the sea. Water pollution issues may also arise in highly populated coasts because of the inevitable water stagnation.

Enhancement of sediment accretion: Sediment accretion is expected to be the only dependable method

5 whereby mangrove growth could occur at the same pace as SLR and soil consolidation. It is also expected that the sediment accretion would further facilitate the growth of vegetation by providing a nutrient-rich substrate, and that erosion of the embankment would decrease because hydraulic energy is dissipated by the vegetation. Therefore, these considerations relating to how the sediment accretion could be promoted may be critical to successful mangrove embankment designs.

10

Oscillation of the mean sea level should be considered: Shallower water depths results in greater efficacy at reducing tidal propagation. Therefore, further increased attenuation is expected if the water depth can be lower than $30 \mathrm{~cm}$, as shown in Figures 4 and 5. However, it should be noted that the MSL is not stable; rather, the MSL fluctuates over time because of inter-annual sea surface oscillations or other mechanisms. One such variation is the El Niño Southern Oscillation (ENSO). Given these uncertainties, the MSL should not be underestimated.

\section{CONCLUSIONS}

In this study, the function of mangrove embankments in attenuating the amplitudes of ocean tides was investigated by developing a numerical model that couples shallow-water wave and soil consolidation models. The proposed model is able to simulate tidal propagation over an artificial embankment that is subjected to SLR, land subsidence, vegetation growth and sediment accretion. The parametric analysis demonstrates that tidal amplitudes could be reduced only if the initial embankment is appropriately designed, such that an equilibrium state of the platform could be achieved over the long term. Although SLR and subsidence are both unavoidable, sediment accretion may only raise the ground and keep the mangrove surface level with the sea level. Sediment accretion is also critical to enhance vegetation growth, which in turn brings more sedimentation by creating a tranquil water environment. The results of the proposed model suggest that an insufficient initial embankment elevation will be less effective against tidal propagation after it undergoes significant subsidence. For example, the tidal amplitude is not effectively reduced by the embankment without a vegetation cover at the constant water depth of $1 \mathrm{~m}$. On the other hand, the maximum attenuation of $64 \%$ is achieved when the vegetation is fully grown, the shallow water depth is $30 \mathrm{~cm}$ and the embankment width is $500 \mathrm{~m}$. 
Nat. Hazards Earth Syst. Sci. Discuss., doi:10.5194/nhess-2017-61, 2017

Manuscript under review for journal Nat. Hazards Earth Syst. Sci.

Discussion started: 20 February 2017

(c) Author(s) 2017. CC-BY 3.0 License.

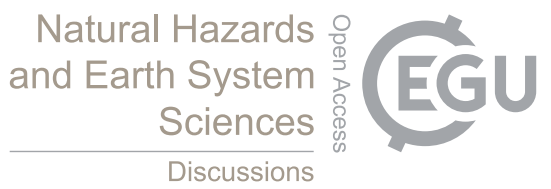

(c) (i)

\section{ACKNOWLEDGEMENTS}

Funding for this research was supported by grants to Tokyo Institute of Technology from JSPS KAKENHI (16KK0121), the Sumitomo Foundation and the Environment Research and Technology Development Fund (S14) of the Ministry of the Environment, Japan.

\section{REFERENCES}

Alongi, D. M., 2008. Mangrove forests: Resilience, protection from tsunamis, and responses to global climate change. Estuarine, Coastal and Shelf Science, 76, pp. 1-13.

Arcement, Jr., G. J., Schneider, V. R., 1984. Guide for selecting Manning's roughness coefficients for natural channels and flood plains. Report No. FHWA-TS-84-204, Federal Highway Administration.

10 Blum, L. K., Christian, R. R., 2004. Belowground production and decomposition along a tidal gradient in a Virginia salt marsh. IN: The Ecogeomorphology of Salt Marshes, American Geophysical Union, pp. 47-74.

Bricker, J. D., Gibson, S., Takagi, H., Imamura, F., 2015. On the need for larger Manning's roughness coefficients in depth-integrated tsunami inundation models. Coastal Engineering Journal, 57(2), 13 pages, DOI: $10.1142 / \mathrm{S} 0578563415500059$.

CNRD-PEDRR, 2013. Disasters, Environment and Risk Reduction - Eco-DRR Master's Module, Instructor's Manual. Center for Natural Resources and Development, Partnership on Environment and Disaster Risk Reduction, 102 pages.

Chaussard E., Amelung F., Adibin H., Hong S-H., 2013. Sinking cities in Indonesia: ALOS PALSAR detects rapid subsidence due to groundwater and gas extraction. Remote Sensing of Environment, 128, pp. 150-161.

Day, J. W., Jr., Templet, P. H., 1989. Consequences of sea level rise: implication from the Mississippi Delta. Coastal Management, 17, pp. 241-257.

Diaz, R. G., 2005. Analysis of Manning coefficient for small-depth flows on vegetated beds. Hydrological Processes, 19, pp. 3221-3233.

Ellison, J. C., 2009. Geomorphology and sedimentology of mangroves. IN: Perillo, G. M. E., Wolanski, E., Cahoon, D. R., Brinson, M. M. (eds), Coastal Wetlands: An Integrated Ecosystem Approach, Elsevier, pp. 563-591.

Furukawa K., Wolanski E., 1996. Sedimentation in mangrove forests. Mangroves and Salt Marshes, 1(1), pp. 310. 
Nat. Hazards Earth Syst. Sci. Discuss., doi:10.5194/nhess-2017-61, 2017

Manuscript under review for journal Nat. Hazards Earth Syst. Sci.

Discussion started: 20 February 2017

(c) Author(s) 2017. CC-BY 3.0 License.

Furukawa, K., Wolanski, E., Mueller, H., 1997. Currents and sediment transport in mangrove forests. Estuarine, Coastal and Shelf Science, 44, pp. 301-310.

Giosan, L., Syvitski, J., Constantinescu, S., Day J., 2014. Protect the world's deltas. Nature, 516, pp. 31-33.

Global Nature Fund, 2007. Mangrove Rehabilitation Guidebook, Global Nature Fund, 69 pages.

5 Green, J. C., 2005. Modelling flow resistance in vegetated streams: Review and development of new theory. Hydrological Processes, 19, pp. 1245-1259.

Gunderson, L.H., Holling, C.S., Pritchard Jr., L., Peterson, G.D., 2002. Resilience of large-scale resource systems. IN: Gunderson, L.H., Pritchard Jr., L. (Eds.), Resilience and the Behaviour of Large-Scale Systems, Island Press, pp. 3-20.

Iimura, K., Tanaka N., 2012. Numerical simulation estimating effects of tree density distribution in coastal forest on tsunami mitigation. Ocean Engineering, 54, pp. 223-232.

Irtem, E., Gedik, N., Kabdasli, M. S., Yasa, N. E., 2009. Coastal forest effects on tsunami run-up heights. Ocean Engineering, 36, pp. 313-320.

Kearney, M. S., Stevenson, J. C., Ward, L. G., 1994. Spatial and temporal changes in marsh vertical accretion rates at Monie Bay: Implication for sea-level rise. Journal of Coastal Research, 10, pp. 1010-1020.

Knappett, J. A., Craig, R. F., 2011. Craig's Soil Mechanics Eighth Edition, CRC Press, 552 pages.

Kowalik, Z., Murty, T. S., 1993. Numerical Modeling of Ocean Dynamics. World Scientific, 481 pages.

Krauss, K. W., McKee, K. L., Lovelock, C. E., Cahoon, D. R., Saintilan, N., Reef, R., Chen, L., 2014. How mangrove forests adjust to rising sea level. New Phytologist, 202, pp. 19-34.

Lynch, J. C., Meriwether, J. R., McKee, B. A., Vera-Herrera, F., Twilley, R. R., 1989. Recent accretion in mangrove ecosystems based on 137Cs and 210Pb. Estuaries, 12, pp. 284-299.

Lovelock, C. E., Cahoon, D. R., Friess, D. A., Guntenspergen, G. R., Krauss, K. W., Reef, R., Rogers, K., Saunders, M. L., Sidik, F., Swales, A., Saintilan, N., Thuyen, L. X., Triet, T., 2015. The vulnerability of Indo-Pacific mangrove forests to sea-level rise. Nature, 526.

Losada, I. J., Maza M., Lara J. L., 2016. A new formulation for vegetation-induced damping under combined waves and currents. Coastal Engineering, 107, pp. 1-13., DOI:10.1016/j.coastaleng.2015.09.011.

Maza, M., Lara, J. L., Losada, I. J., 2015. Tsunami wave interaction with mangrove forests: a 3-D numerical approach. Coastal Engineering, 98, pp. 33-54., DOI: 10.1016/j.coastaleng.2015.01.002.

Mazda, Y., Wolanski, E., King, B., Sase, A., Ohtsuka, D., Magi, M., 1997. Drag force due to vegetation in mangrove swamps. Mangroves and Salt Marshes, 1, pp. 193-199. 
Nat. Hazards Earth Syst. Sci. Discuss., doi:10.5194/nhess-2017-61, 2017

Manuscript under review for journal Nat. Hazards Earth Syst. Sci.

Discussion started: 20 February 2017

(c) Author(s) 2017. CC-BY 3.0 License.

Mazda, Y., Kamiyama, K., 2007. Tidal deformation and inundation characteristics within mangrove swamps. Mangrove Science, 4/5, pp. 21-29.

Mikami, T., Shibayama, T., Takagi, H., Matsumaru, R., Esteban, M. Nguyen, D.T., de Leon, M., Valenzuela, V. P., Oyama, T., Nakamura, R., Kumagai, K., Li, S., 2016. Storm surge heights and damage caused by the 2013 typhoon Haiyan along the Leyte Gulf coast. Coastal Engineering Journal, 58(1), pp. 1640005. DOI: $10.1142 / \mathrm{S} 0578563416400052$.

Narayan, S., Suzuki, T., Stive, M. J. F., Verhagen, H. J., Ursem, W. N. J., Ranasinghe, R. 2010. On the effectiveness of mangroves in attenuating cyclone-induced waves. Coastal Engineering, 12 pages.

Oka, S., Orishimo, S., Nagano, A., 2004. Natural symbiosis type fishing port rehabilitation using the mangrove (example of the Jakarta fishing port). Proceedings of Civil Engineering in the Ocean, JSCE, 20, pp. 11511156.

Osterberg, J. O., 1957. Influence values for vertical stresses in a semi infinite mass due to an embankment loading. Proceedings of the Fourth International Conference on Soil Mechanics and Foundation Engineering, 1, pp. 393-394.

Parkinson, R. W., DeLaune, R. D., White J. R., 1994. Holocene sea-level rise and the fate of mangrove forests within the wider Caribbean region. Journal of Coastal Research, 10, pp. 1077-1086.

Primavera, J. H., Esteban, J. M. A., 2008. A review of mangrove rehabilitation in the Philippines: successes, failures and future prospects. Wetlands Ecology and Management, 16, pp. 345-358.

Rasmeemasmuang, T., Sasaki J., 2015. Wave reduction in mangrove forests: general information and case study in Thailand. IN: Handbook of Coastal Disaster Mitigation for Engineers and Planners, pp. 511-535, DOI: 10.1016/B978-0-12-801060-0.00024-1.

Saad, S., Husain, M. L., Yaacob, R., Asano, T., 1999. Sediment accretion and variability of sedimentological characteristics of a tropical estuarine mangrove: Kemaman, Terengganu, Malaysia. Mangroves and Salt Marshes 3, pp. 51-58.

Strusinska-Correia, A., Husrin, S., Oumeraci, H., 2013. Tsunami damping by mangrove forest: a laboratory study using parameterized trees. Natural Hazards and Earth System Sciences, 13, pp. 483-503, DOI:10.5194/nhess-13-483-2013.

Takagi, H., Mikami, T., Fujii, D., Esteban, M., 2016a. Mangrove forest against dyke-break induced tsunami in rapidly subsiding coasts. Natural Hazards and Earth System Sciences, 16, pp. 1629-1638, DOI:10.5194/nhess-2016-128. 
Nat. Hazards Earth Syst. Sci. Discuss., doi:10.5194/nhess-2017-61, 2017

Manuscript under review for journal Nat. Hazards Earth Syst. Sci.

Discussion started: 20 February 2017

(c) Author(s) 2017. CC-BY 3.0 License.

Takagi, H., Esteban, M., Mikami, T., Fujii, D., 2016b. Projection of coastal floods in 2050 Jakarta. Urban Climate, 17, pp.135-145, DOI: 10.1016/j.uclim.2016.05.003.

Takagi, H., Thao, N. D., Anh, L. T., 2016c. Sea-level rise and land subsidence: impacts on flood projections for the Mekong delta's largest city. Sustainability, 8(9), DOI: 10.3390/su8090959.

5 Tang, J., Shen, Y., Causon, D. M, Qian, L., Mingham, C. G., 2017. Numerical study of periodic long wave runup on a rigid vegetation sloping beach. Coastal Engineering, 121, pp. 158-166.

Teh, S. Y., Koh, H. L., Liu, P. L., Ismail, A. I., Lee, H. L., 2009. Analytical and numerical simulation of tsunami mitigation by mangroves in Penang, Malaysia. Journal of Asian Earth Sciences, 36, pp. 38-46.

UNEP, 2012. Applying ecosystem-based approaches for disaster risk reduction and climate change adaptation. General Assembly Thematic Debate on Disaster Risk Reduction, New York, 2 pages.

UNEP, 2015. Promoting ecosystems for disaster risk reduction and climate change adaptation. Discussion Paper, 52 pages.

Vuik, V., Jonkman, S. N., Borsje, B. W., Suzuki, T., 2016. Nature-based flood protection: the efficiency of vegetated foreshores for reducing wave loads on coastal dikes. Coastal Engineering, 116, pp. 42-56.

15 Wesley, L. D., 2010. Fundamentals of Soil Mechanics for Sedimentary and Residual Soils, Wiley, 431 pages, ISBN 978-0-470-37626-3.

Woodroffe, C., 1992. Mangrove sediments and geomorphology. IN: Robertson A. I., Alongi D.M. (eds), Tropical Mangrove Ecosystem, American Geophysical Union, pp. 7-41.

Wood, M. E., Kelley, J. T., Belknap, D. F., 1989. Patterns of sediment accumulation in the tidal marshes of Maine. Estuaries, 12, pp. 237-246.

Wolanski, E., Jones, M., Bunt, J. S., 1980. Hydrodynamics of a tidal creek-mangrove swamp system. Australian Journal of Marine and Freshwater Research, 31, pp. 431-450.

Wolanski, E., Brinson, M. M., Cahoon, D. R., Perillo, G. M. E., 2009. Coastal wetlands: a synthesis, IN: Perillo, G. M. E., Wolanski, E., Cahoon, D. R., Brinson, M. M. (eds), Coastal Wetlands: An Integrated Ecosystem Approach, Elsevier, pp. 1-62.

Xu, H. Z., Zhang, K. Q., Shen, J. A., Li, Y. P., 2010. Storm surge simulation along the U. S. east and gulf coasts using a multi-scale numerical model approach. Ocean Dynamics, 60(6), pp. 1597-1619. 
Nat. Hazards Earth Syst. Sci. Discuss., doi:10.5194/nhess-2017-61, 2017

Manuscript under review for journal Nat. Hazards Earth Syst. Sci.

Discussion started: 20 February 2017

(c) Author(s) 2017. CC-BY 3.0 License.
Natural Hazards and Earth System

Sciences

Discussions

(c) (1)

(a)

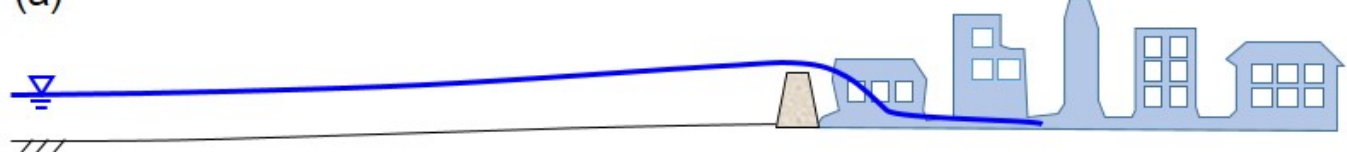

TII

(b)
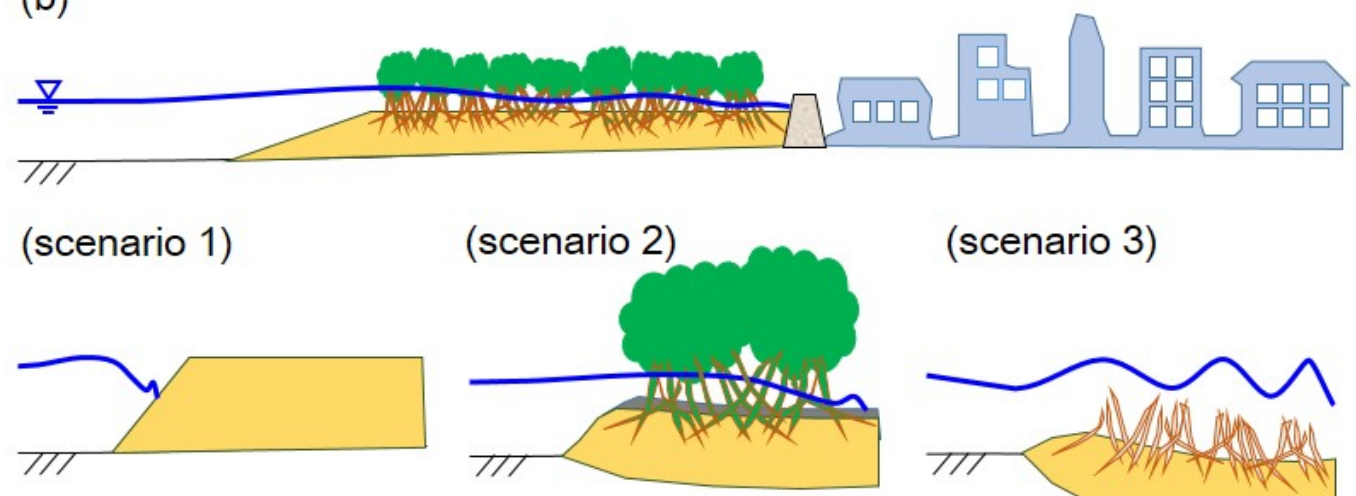

(scenario 3)

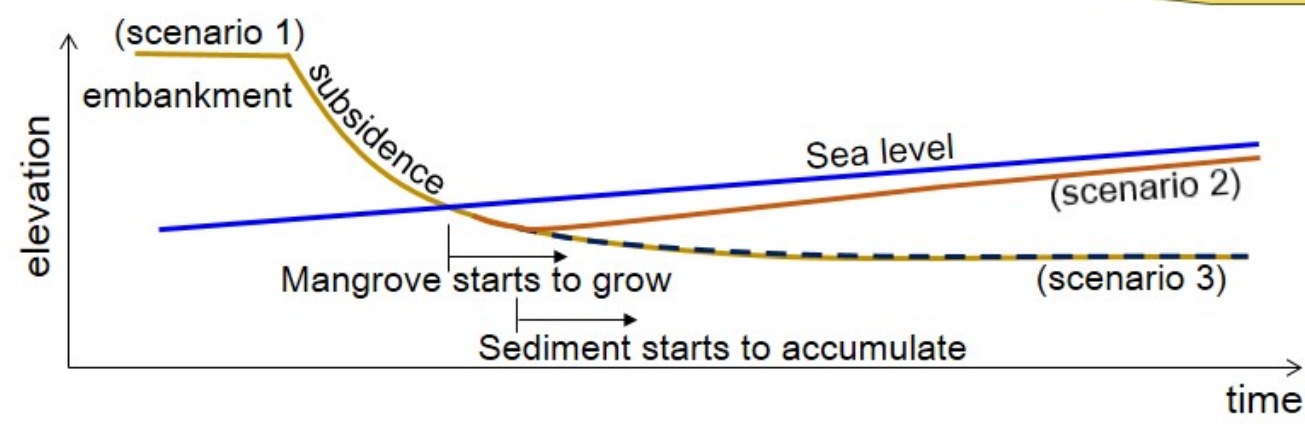

Figure 1. Artificial mangrove embankments and their transitions over time: (Scenario 1) initial dimension of the embankment; (Scenario 2) rate of subsidence is balanced with the pace of SLR; and (Scenario 3) rate of subsidence is excessive and does not sufficiently mitigate tides or wind waves. 
Nat. Hazards Earth Syst. Sci. Discuss., doi:10.5194/nhess-2017-61, 2017

Manuscript under review for journal Nat. Hazards Earth Syst. Sci.

Discussion started: 20 February 2017

(c) Author(s) 2017. CC-BY 3.0 License.

\section{(c) (1)}

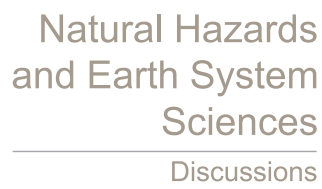

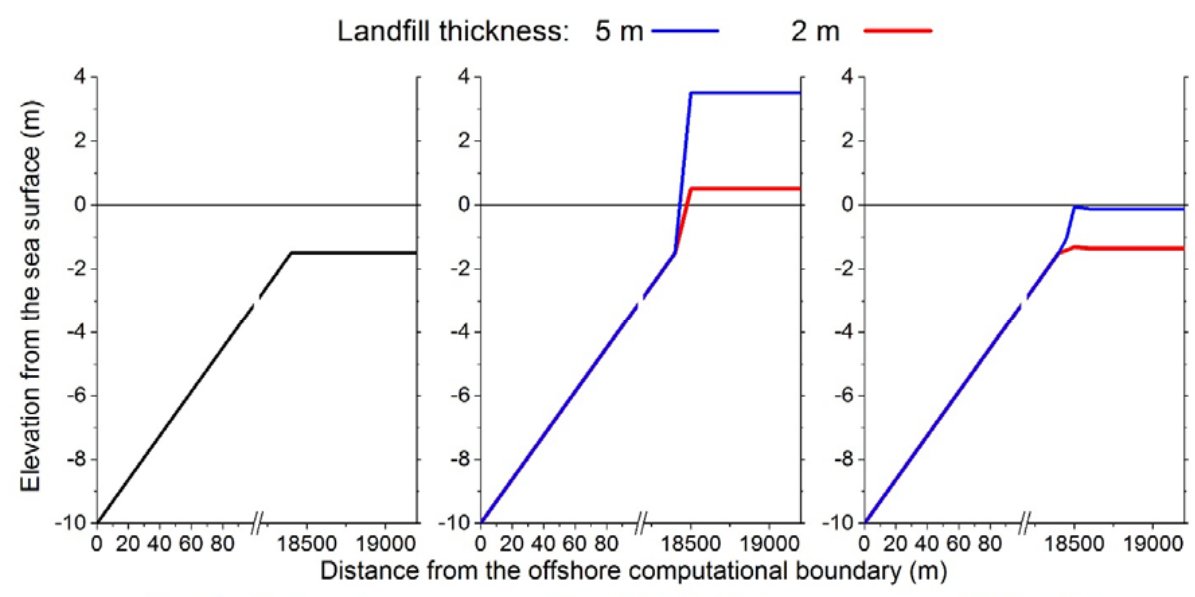

(a) original bathymetry

(b) landfill completed

(c) 60 yrs later

Figure 2. Transitions of mangrove platforms with two different initial heights.

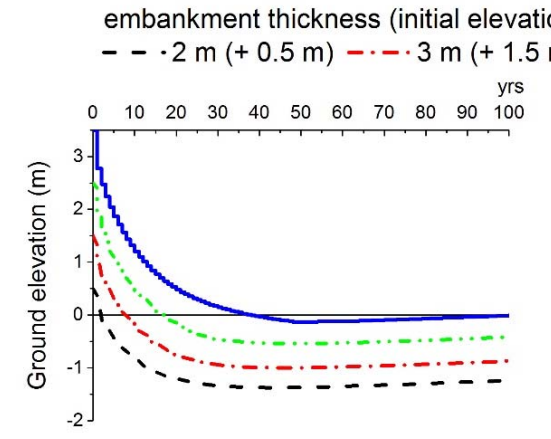

(a) with sediment deposition

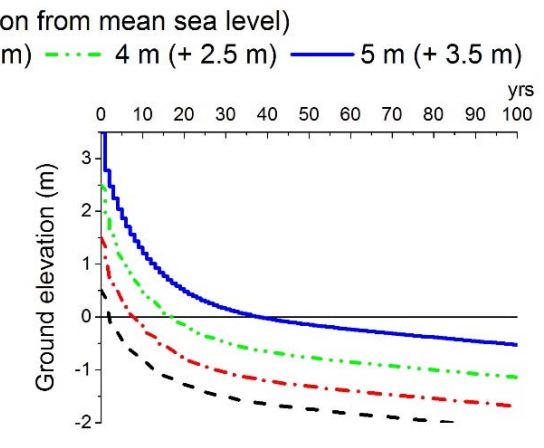

(b) without sediment deposition

5 Figure 3. Changes in ground elevation over one century (a) with sediment deposition, and (b) without deposition. The elevations are monitored at $500 \mathrm{~m}$ inland from the shoulder of the mangrove embankment (i.e., the location at $19000 \mathrm{~m}$ in Figure 2). 
Nat. Hazards Earth Syst. Sci. Discuss., doi:10.5194/nhess-2017-61, 2017

Manuscript under review for journal Nat. Hazards Earth Syst. Sci.

Discussion started: 20 February 2017

(c) Author(s) 2017. CC-BY 3.0 License.
Natural Hazards and Earth System

Sciences

Discussions

(c) (i)
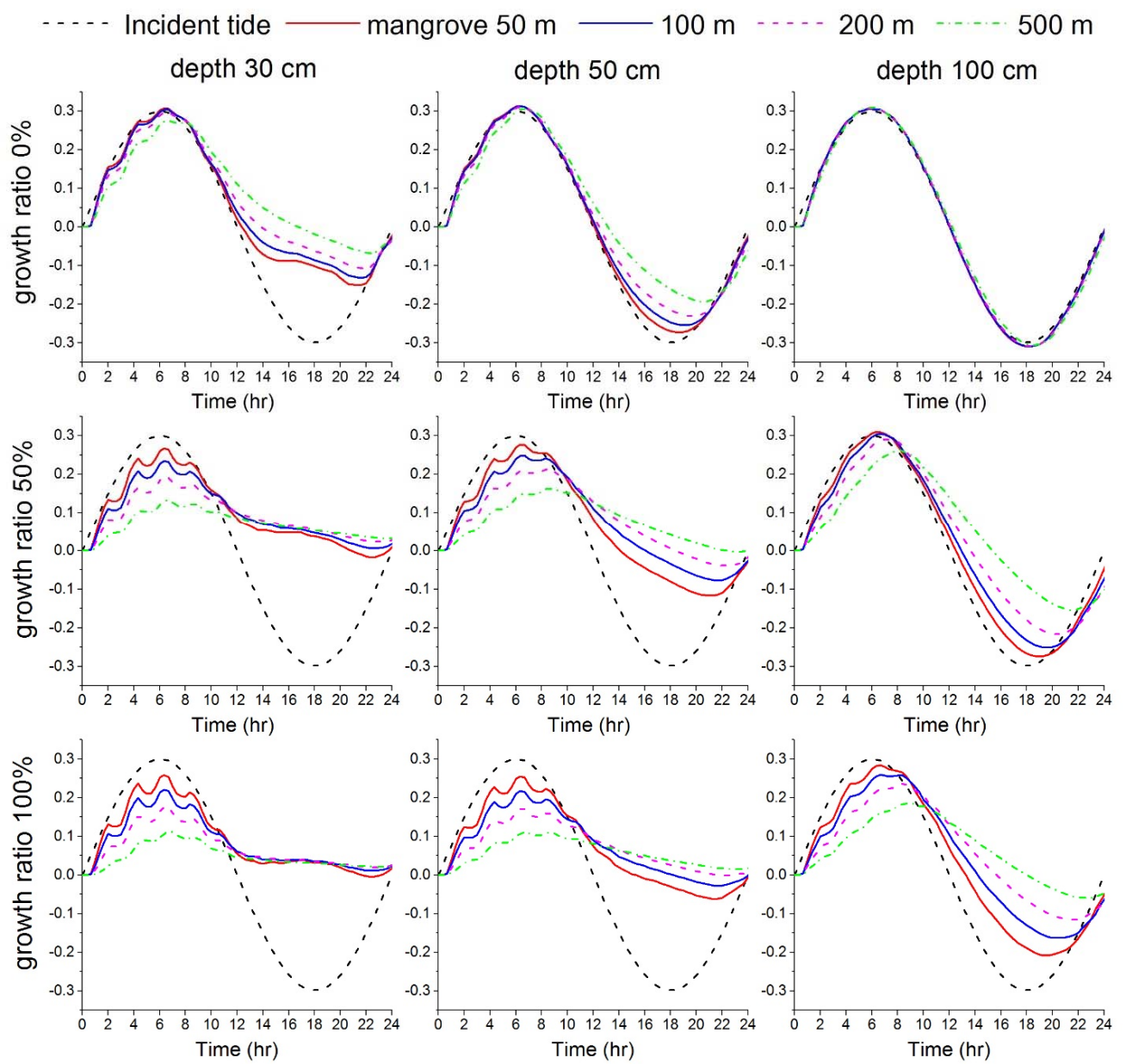

Figure 4. Tidal propagations over the mangrove embankments with widths of 50, 100, 200 and $500 \mathrm{~m}$; the tidal propagations are influenced by vegetation growth rates and water depth. 
Nat. Hazards Earth Syst. Sci. Discuss., doi:10.5194/nhess-2017-61, 2017

Manuscript under review for journal Nat. Hazards Earth Syst. Sci.

Discussion started: 20 February 2017

(c) Author(s) 2017. CC-BY 3.0 License.

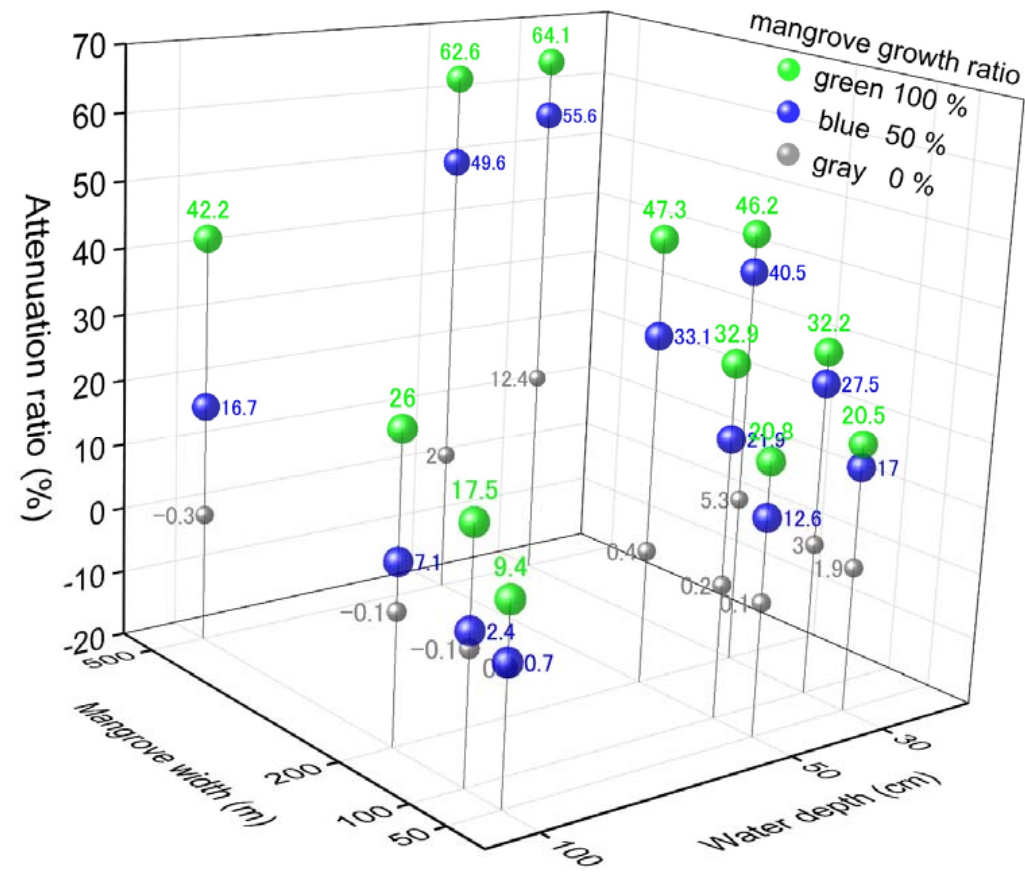

Figure 5. Simulated attenuation ratios in tidal amplitude, varying with mangrove width, water depth and growth ratio.

Table. 1 Manning's $n$ values according to vegetation condition as presented in past studies

\begin{tabular}{l|l|l|l|l}
\hline $\begin{array}{c}\text { Manning's } n \\
\text { value } \\
\left(\mathrm{s} \mathrm{m}^{-1 / 3}\right)\end{array}$ & \multicolumn{1}{|c|}{ Event } & \multicolumn{1}{|c}{ Location } & \multicolumn{1}{|c}{ Vegetation type } \\
\hline $0.2-0.4$ & Tide & $\begin{array}{l}\text { Coral Creek, Queensland, } \\
\text { Australia }\end{array}$ & Mangrove & $\begin{array}{l}\text { Wolanski et al. } \\
(1980)\end{array}$ \\
\hline $0.1-0.2$ & Flood & $\begin{array}{l}\text { Various flood plains in the } \\
\text { US }\end{array}$ & $\begin{array}{l}\text { Dense bushy willow, } \\
\text { etc. }\end{array}$ & $\begin{array}{l}\text { Arcement and } \\
\text { Schneider (1984) }\end{array}$ \\
\hline $0.2-0.7$ & Tide & $\begin{array}{l}\text { Nakama-Gawa, Okinawa, } \\
\text { Japan }\end{array}$ & Mangrove & $\begin{array}{l}\text { Mazda } \text { et al. } \\
(1997)\end{array}$ \\
\hline 0.1 & Tide & $\begin{array}{l}\text { Middle Creek, Cairns, } \\
\text { Australia }\end{array}$ & Mangrove & $\begin{array}{l}\text { Furukawa } \text { et al. } \\
(1997)\end{array}$ \\
\hline 0.15 & Storm surge & South Florida, US & Mangrove & Xu et al. (2010) \\
\hline $0.075-0.505$ & $\begin{array}{l}\text { Field channel } \\
\text { test }\end{array}$ & $\begin{array}{l}\text { Guadalajara, Castilla la } \\
\text { Mancha, Spain }\end{array}$ & $\begin{array}{l}\text { Grassland, Scrubland, } \\
\text { Pine forest }\end{array}$ & Diaz (2005) \\
\hline
\end{tabular}

